\title{
Early Social Communication Profile of Korean Late Talkers via the CSBS DP
}

\author{
YoonKyoung Lee, HyoJoo Lee \\ Division of Speech Pathology and Audiology, Hallym University, Chuncheon, Korea
}

Correspondence: YoonKyoung Lee, $\mathrm{PhD}$ Division of Speech Pathology and Audiology, Hallym University, 1 Hallimdaehak-gil, Chuncheon 24252, Korea

Tel: +82-33-248-2219

Fax: +82-33-256-3420

E-mail: ylee@hallym.ac.kr

Received: April 25, 2019

Revised: May 27, 2019

Accepted: May 27, 2019

This research was supported by Hallym University Research Fund 2019 (No. HRF-201904-010).

\begin{abstract}
Objectives: This study aimed to examine the early social communication abilities of late talking toddlers compared to typically developing toddlers that were matched to both chronological age and language age. Methods: Eighteen late talking toddlers (LT) aged between 18-36 months, 18 toddlers matched to chronological age (CA group) and 18 toddlers matched to language age (LA group) participated in the study. The social communication abilities of toddlers of the three groups were assessed using the Korean edition of the Communication and Symbolic Behavior Scale Developmental Profile (K-CSBS DP) and scored based on the K-CSBS DP scoring systems. A one-way ANOVA was performed for comparing the results of three toddler groups. Results: The LT group showed a significantly lower total score on the K-CSBS DP than the CA group only. In the case of cluster scores, the LT group showed significantly lower scores on the communication, sounds, and words cluster than the CA group; however, significantly higher scores on the emotion and gaze, language comprehension, and object use cluster than the LA group. Conclusion: The findings of this study show LT's social communication abilities developed slower than their age matched peers. In particular, they are vulnerable to speech and intentional communication behaviors, while language understanding and object use are intact. The results of the study have been discussed in relation to the implications for prognosis and intervention of LT.
\end{abstract}

Keywords: Late talkers, Late-talking toddlers, Social communication, K-CSBS DP
말늦은 영유아(late talker)는 인지나 사회성, 신경학적 발달 등 언어 이외의 다른 영역에서는 특별한 문제를 보이지 않고 표현언어 발달이 유의하게 지체된 영유아를 말한다(Paul, 1991, 1993; Rescorla, 1989, 2011). 초창기에는 표현언어발달지체(early expressive language delay 또는 slow expressive language development; Paul, 1991, 1993), 언어발달지체(language delay 또는 developmental language delay; Horwitz et al., 2003; Whitehurst \& Fischel, 1994) 와 같이 '발달지체’로 표현되기도 하였으나, 최근에는 말늦은 영유 아 혹은 느린 언어출현(late language emergence, LLE; Taylor, Zubrick, \& Rice, 2013) 표현이 보편적으로 사용되고 있다. 연구자들이 언어발달지체 혹은 언어발달장애라는 표현 대신에 '말늦은 영유 아'라는 표현을 선호하게 된 이유는 출생에서 3 세까지는 다른 시기 에 비해 발달적 변화가 크고, 발달에서의 개인차가 큰 시기이기 때 문에 다른 발달에서는 큰 문제없이 언어, 특히 표현언어에서만 느린
영유아를 언어발달지체나 언어발달장애로 섣불리 진단하거나 구 분하지 않으려는 것이다.

실제로 말늦은 영유아들 중 상당수가 이후 점차 언어발달을 회 복하여 또래 수준에 도달하는 경우가 많다고 보고된다(Dale, Price, Bishop, \& Plomin, 2003; Henrichs et al., 2011; Paul, Looney, \& Dahm, 1991; Tomblin et al., 1997; Westerlund, Berglund, \& Eriksson, 2006). 말늦은 영유아는 대략적으로 해당 연령의 약 $10 \%-20 \%$ 정도를 차 지한다고 알려져 있는데(Desmarais, Sylvestre, Meyer, Bairati, \& Rouleau, 2008; Klee et al., 1998), 이들 중 상당수는 유아기와 아동 기까지 계속 언어발달 문제를 유지하여 단순언어장애(specific language impairment, SLI)로 진단받기도 하지만 상당수는 뒤늦게 언 어발달이 회복되어 전형적 발달전형적 발달을 회복하는 말늦은 상 태를 벗어난 아동(recovered late talkers, RLT) 또는 늦되는 아동 (late bloomer)이 된다(Paul, 1991; Rescorla, Roberts, \& Dahlsgaard, 
1997). 연구마다 차이가 있으나 말늦은 영유아 중 이후 단순언어장 애로 진단받는 경우가 약 20\%-50\% 정도 된다고 보고되고 나머지 는 생활연령에 적합한 언어발달을 회복한다고 보고된다. 종단적 추 적연구를 통해 Paul 등(1991), Dale 등(2003)은 30개월 미만에 말늦 은 영유아로 진단된 영유아 중 절반에 가까운 약 $40 \%-50 \%$ 의 영유 아가 3세 이후에도 지속적인 언어발달지연을 나타냈다고 보고한 반면 Tomblin 등(1997)과 Henrichs 등(2011)은 29\%, Westerlund 등(2006)은 $18 \%$ 의 영유아만이 3세 이후까지 지속적인 언어발달지 체를 보였을 뿐 대부분 정상 범위의 언어발달을 회복하였다고 보고 하였다.

말 느린 영유아 중 누가 언어발달을 회복할 것이며, 혹은 지속적 으로 언어발달을 보일 것인지, 그리고 이 두 집단의 영유아를 구분 하게 하는 요인이 무엇인지를 확인하는 것은 이후 발달을 예측하 는 데에는 물론 조기 개입 여부를 결정할 때 중요한 정보가 된다 (Paul et al., 1991). 보통 말늦은 영유아의 주된 판별기준이 되어 온 표현어휘수나 낱말조합 여부보다 먼저 발달하는 것으로 알려진 수 용언어(Carson, Klee, Perry, Muskina, \& Donaghy, 1998), 의사소 통적 몸짓 사용과 이해(Lee \& Lee, 2015; Thal, Tobias, \& Morrison, 1991), 의도적 의사소통행동(Rescorla \& Merrin, 1998), 음절 내에 서의 자음 사용이나 자음 목록과 같은 말소리 발달(Carson et al., 1998; Mirak \& Rescorla, 1998; Paul \& Jennings, 1992), 상징발달 (Rescorla \& Goossens, 1992) 등과 같은 사회적 의사소통 측면이 연 구되어 왔으며, 말늦은 영유아들이 이 영역에서도 또래에 비해 느 리거나 취약함을 보였다고 보고되었다. 또한 의사소통을 목적으로 사용된 몸짓이나 말소리 사용, 의도적 의사소통행동 비율 등이 이 후의 언어발달을 확인할 수 있는 요인이 될 수 있다고 보고되기도 하였다(Choi \& Lee, 2018; Hong \& Kim, 2005; Thal \& Tobias, 1992).

그러나 말늦은 영유아가 이러한 초기 사회적 의사소통 영역 중 어떠한 영역에서 유의하게 발달이 느린지, 이러한 초기 사회적 의사 소통 발달이 이후 언어발달에 미치는 영향력에 대해서는 연구자들 에 따라 이견을 보였다. Rescorla (2011)는 말늦은 영유아의 언어발 달에 대한 연구들에 대한 문헌 검토를 통해, 수용언어, 몸짓과 놀이 발달, 자음 목록, 읽기 문제와 관련된 가족력 등이 이후 언어발달 정도를 예측하는 요인임을 명확히 하였으나 각각의 요인이 미치는 영향력 정도는 분명하지 않다고 하였다. 반면, 영유아기 언어발달 에 대한 전향적 코호트 연구로 잘 알려진 Victoria 연구(Early Language in Victoria Study, ELVS; Reilly et al., 2009)에서는 연구에 참 여한 1,720 명 중 약 20 명 정도가 말늦은 영유아에 해당하였다고 보 고하였는데, 성별이나 출생 시 몸무게, 출생 순위, 사회경제적지위 등과 같은 요인이 느린 언어발달의 $7 \%$ 를 설명한 반면, 의사소통 및
상징행동 척도(Communication and Symbolic Behavior Scales Development Profile, CSBS DP; Wetherby \& Prizant, 2002) 중 선 별검사인 '영유아 체크리스트(Infant-Toddler Checklist)' 결과가 $14 \%$ 를 설명하였다고 보고하여 초기 사회적 의사소통행동 발달 정 도가 말늦은 영유아의 행동을 확인하게 해 주는 요인이 될 수 있음 을 보고하기도 하였다.

앞서 살펴본 연구들은 영향력의 정도에서는 이견이 있으나 대체 로 말늦은 영유아들이 표현언어 발달만이 아니라 초기 사회적 의 사소통행동 발달도 느린 경향이 있으며, 이러한 초기 사회적 의사 소통 발달 정도가 이후 언어발달 정도를 예측하는 요인이 될 수 있 음을 보여 준다. 그러나 선행연구들은 초기 사회적 의사소통에 포 함된 행동을 개별적으로 살펴본 경우가 대부분이어서 초기 말늦 은 영유아가 사회적 의사소통행동 발달에서 어떠한 행동에서 특히 취약함을 보이고 어떠한 행동에서 강점을 보이는지 전반적인 프로 파일을 보여주는 경우는 드물며, 말늦은 영유아의 수행을 생활연 령이 동일한 또래와만 비교하여 언어발달 정도와는 어떠한 관계에 있는지는 명확하게 설명하지 않는 경우가 대부분이다.

본 연구는 이러한 배경하에 CSBS DP 행동관찰검사를 이용하여 말늦은 영유아의 사회적 의사소통 행동 프로파일을 확인하고자 하였다. CSBS DP는 영유아기의 사회적 의사소통 능력을 평가하기 위해 개발된 검사도구로 초기 사회적 의사소통행동 발달 양상을 확인하는 데 타당한 검사로 평가된다. 특히 행동샘플검사는 체계 화된 관찰과 채점 방법을 고안하여 영유아의 초기 사회적 의사소 통행동 발달을 보다 용이하면서도 신뢰롭게 측정할 수 있도록 하며 (Crais, 2011), 최근 국내 영아들을 대상으로도 신뢰도와 타당도가 보고된 바 있다(Lee, Lee, \& Choi, 2018).

본 연구에서는 또한 말늦은 영유아의 초기 사회적 의사소통행 동을 생활연령을 일치시킨 일반 영유아만이 아니라 언어연령을 일 치시킨 일반 영유아 집단과 비교하여 이들의 사회적 의사소통행동 발달이 단지 생활연령에 비해 지연된 양상으로 나타나는지, 언어발 달과는 어떠한 관계에 있는지를 확인하고자 하였다.

\section{연구방법}

\section{연구 대상}

본 연구는 생활연령이 18 개월에서 35 개월 사이에 있는 말늦은 영 유아 18 명과 이들과 생활연령을 일치시킨 일반 영유아 18 명, 언어연 령을 일치시킨 일반 영유아 18 명, 총 54 명의 영유아를 대상으로 하 였다. 모든 자료는 CSBS DP 한국판 표준화 연구에 참여한 영유아 자료에서 추출한 것이었으며, 표준화 연구 참여 시 보호자로부터 
추후 연구목적으로의 자료 사용에 동의한 자료만을 사용하였다.

말늦은 영유아의 선정기준은 다음과 같았다. (1) 생활연령이 18-35개월 사이에 있는 영유아: 말늦은 영유아에 대한 선행연구에 서 Rescorla $(2002,2005,2009)$ 는 24-31개월 사이에 있는 영유아를, Paul (1991)은 18-34개월, Thal, Oroz와 McCaw (1995)는 18-33개 월 사이의 영유아를 포함하여 다양한 생활연령 기준이 사용되었 다. Rescorla (2011)는 이를 종합하여 18-35개월 사이의 연령범위를 제시하였는데, 본 연구에서는 이를 따랐다. (2) 표현언어능력이 영 유아 언어발달검사(Sequenced Language Scale for Infants, SELSI; Kim, Kim, Yoon, \& Kim, 2003)에서 10백분위수 이하로 생활연령 에 비해 유의하게 지체되어 있는 영유아: 이 시기의 표현언어발달은 표현어휘수나 낱말조합 여부로 평가될 수 있다. 때문에 24개월경에 표현어휘수가 50개 미만이고 두 낱말조합을 시작하지 않은 경우를 말늦은 영유아의 판별기준으로 사용해 왔으나 이와 더불어 표준화 된 언어검사의 표현언어 결과가 생활연령에 비해 유의하게 지체된 경우를 기준으로 하기도 한다(Bavin \& Bretherton, 2013). 선행연 구들은 이 시기 언어발달을 신뢰롭게 평가하는 것으로 알려진 Language Developmental Survey (Rescorla, 1989)나 MacArthurBates Communicative Development Inventories (M-B CDI; Fenson, 2007)의 어휘 및 문법 체크리스트를 주로 판별 도구로 사용하 였으나, Ages \& Stages Qustionnaires (ASQ; Bricker et al., 1999)와 같은 발달검사의 의사소통영역 검사로 사용하기도 하였다. 지체 기 준은 15 백분위수 이하(Rescorla \& Achenbach, 2002)의 기준을 적 용한 경우도 있으나 보통 10백분위수 이하(Dale et al., 2003; Ellis Weismer \& Evans, 2002)가 많이 사용되었다. 본 연구에서는 국내 영유아를 대상으로 표준화된 SELSI 표현언어검사에서 10 백분위 수 미만인 경우를 기준으로 하였다. (3) 수용언어능력이 생활연령 에 비하여 3-4개월 이내에 있는 경우: 수용언어능력은 연구자에 따 라 기준을 제시한 경우도 있고 제시하지 않은 경우도 있으나, 본 연 구에서는 수용언어능력까지 제한된 경우에는 대체로 다른 발달문 제를 동반한 경우가 많으므로 수용언어발달연령이 생활연령에 비 하여 3-4개월 이내에 있는 경우로 한정한 Rescorla (2009)의 기준 을 따라 기준에 포함하였다. (4) 언어 및 의사소통 영역 이외의 발달 에 문제가 없는 경우: 언어 외 발달 선별을 위해 영아선별교육진단 검사(Development Assessment for the Early Intervention Planning, DEP; Jang, Seo, \& Ha, 2011)의 하위 영역 중 의사소통을 제외 한 다른 영역의 발달이 보통 범위(35-65 백분위, 환산점수 3점) 이 상에 해당하는 경우만 포함하였다.

통제집단인 일반 영유아는 (1) 말늦은 영유아와 생활연령을 일 대일로 일치한 영유아 중에서, (2) DEP의 6가지 하위 영역의 발달
Table 1. Participants' characteristics

\begin{tabular}{lccc}
\hline & LT group (N=18) & CA group (N=18) & LA group (N=18) \\
\hline Chronological age & $21.72(1.81)$ & $21.72(1.81)$ & $15.00(2.20)$ \\
SELSI & & & \\
RLA & $23.50(4.22)$ & $26.06(2.82)$ & $18.72(4.38)$ \\
ELA & $16.94(2.67)$ & $28.06(15.71)$ & $16.94(2.67)$ \\
CLA & $20.11(3.16)$ & $25.44(2.59)$ & $17.78(3.51)$ \\
DEP & & & \\
Gross motor & $3.89(1.13)$ & $4.11(1.28)$ & $3.78(1.11)$ \\
Fine motor & $3.56(0.92)$ & $3.89(1.08)$ & $4.00(0.97)$ \\
Communication & $2.83(1.10)$ & $4.33(1.14)$ & $3.89(1.18)$ \\
Social-emotion & $3.56(1.29)$ & $4.22(1.06)$ & $4.00(0.84)$ \\
Cognition & $4.17(0.92)$ & $3.83(1.34)$ & $4.39(0.98)$ \\
Self-help skills & $3.56(0.92)$ & $4.44(0.98)$ & $4.22(0.81)$ \\
\hline
\end{tabular}

Values are presented as mean (SD).

$\mathrm{LT}=$ late talker; $\mathrm{CA}=$ chronological age matched group; $\mathrm{LA}=$ language age matched group; SELSI = Sequenced of Language Scale for Infants (Kim, Kim, Yoon, \& Kim, 2003); $R L A=$ receptive language age; $E L A=$ expressive language age; $D E P=$ Development Assessment for the Early Intervention Planning (Jang, Seo, \& Ha, 2011).

이 보통 범위(35-65 백분위, 환산점수 3점) 이상에 해당하며, (3) SELSI로 측정한 표현언어와 수용언어가 모두 26백분위수 이상에 해당하는 영유아로, (4) 말늦은 영아와 성별이 같은 영유아 중에서, (5) 생활연령 일치집단은 말늦은 영유아와 생활연령이 1 개월 이내 에 있으며, 언어연령 일치집단은 SELSI로 측정한 표현언어연령이 1 개월 이내에 있는 경우만 포함하였다. 연구 대상자의 정보는 Table 1 과같다.

\section{연구도구}

\section{한국판 CSBS DP 행동샘플검사}

CSBS DP (Wetherby \& Prizant, 2002)는 6개월에서 24개월의 영 아의 의사소통과 상징행동을 평가하기 위해 고안된 검사도구로 행 동샘플검사, 양육자보고검사, 영유아체크리스트(ITC)의 세 검사 로 구성된다. CSBS DP 는 Lee 등(2018)에 의해 한국형으로 번안하 고 신뢰도와 타당도를 검정되었는데, 본 연구에서는 이 중 행동샘 플검사를 연구도구로 사용하였다.

CSBS-DP 행동샘플검사는 검사자가 영유아와 대면하여 행동을 수집한 후 정해져 있는 채점 방식으로 채점하도록 하는 검사로 영 유아의 의사소통 행동을 유도하기 위한 4 가지 유도 절차(태엽인형, 풍선, 비누방울, 병속과자)와 책보기, 소꿉놀이 세트를 이용한 놀 이 활동으로 구성된다. 3 개 구성영역(사회적, 발화적, 상징적), 7 개 의 세부요인(정서-시선, 의사소통, 의사소통 몸짓, 말소리, 낱말, 언 어이해, 사물사용), 20 개의 문항(시선이동, 긍정적 정서표현, 가리키 는 곳 보기, 의도적 의사소통행동 빈도, 행동통제, 사회적 상호작 
용, 공동주의, 관습적 몸짓 목록, 원거리 몸짓, 자음 포함 음절, 자 음 목록, 낱말, 낱말 목록, 낱말조합, 낱말조합 목록, 언어이해, 행동 도식 목록, 타인 대상 행동도식, 연속행동도식, 블록쌓기)으로 구성 되어 있다.

\section{영유아 언어발달검사}

영유아 언어발달검사(SELSI; Kim et al., 2003)는 생후 4-35개월 영유아의 전반적인 언어 및 의사소통 능력을 평가하기 위하여 고안 된 검사로 말늦은 영유아를 선별하기 위한 도구로 포함하였다.SELSI 는 수용언어와 표현언어 각각 56 문항씩 총 112 개의 문항으로 구성 되어 있으며, 대상 영아의 연령 및 검사 수행에 따라 기초선과 최고 한계선을 측정하도록 한다. 화용, 의미, 음운, 문법 등 영유아의 언 어발달에 대한 전반적인 정보를 제공해 준다. 본 연구에서는 수용언 어발달연령, 표현언어발달연령, 통합언어발달연령을 측정하였다.

\section{영아선별교육진단검사}

언어 이외의 발달 평가 목적으로 영아선별교육진단검사(DEP; Jang et al., 2011)를 사용하였다. DEP는 발달지체나 장애 위험군 영 아의 조기선별을 목적으로 개발되었으며, 0-36개월 사이의 영아들 을 대상으로 한다. 검사는 대근육 운동기술, 소근육 운동기술, 의사 소통, 사회정서, 인지, 기본생활의 6 가지 영역으로 구성되어 있다. 검사 결과 해석 기준이 백분위의 범위로 제시되어서 본 연구에서 는 이를 다음과 같은 5점 척도로 측정하였다. 1 은 '매우 느림(20백 분위 이하)', 2 는 '느림(21-35 백분위)', 3 은 '보통(36-65 백분위)', 4 는 '빠름(66-80 백분위)', 5 는 '매우 빠름(80 백분위 이상)'.

\section{자료수집}

자료수집은 연구자 중 한 명이 직접 실시하였으며, 자료수집 보 조자로 석사과정생 2 명이 번갈아 참여하였다. 검사자는 CSBS DP 실시 및 채점 절차에 대한 훈련을 받았으며, 검사 실시 경험이 많은 사람이었다. 석사과정생도 자료수집 절차에 대해 교육과 훈련을 받 은 후 자료수집에 참가하였으며, 자료수집 시 검사와 자료녹화가 원활히 진행되도록 보조하였다.

자료수집은 영유아의 집에서 진행하였다. 검사 시간은 양육자에 게 영유아의 생활 패턴을 문의하여 신체활동이 가장 좋은 시간으 로 결정하였다. 방문 후 먼저 양육자를 대상으로 연구목적과 방법 을 설명하고 연구참여 동의서에 서명을 받았다. 그리고 양육자 보 고를 통해 실시하는 SELSI를 실시하였다. 몇 개의 문항을 함께 체크 한 후에는 양육자가 스스로 기록하게 하였으며, 이해가 되지 않는 문항에 대해서는 검사자에게 내용을 확인받은 후 체크하게 하였다.
한국판 CSBS DP를 실시하기 전에 먼저 가정 내 익숙한 장난감 을 사용하여 10 분 정도 놀이를 진행하여 영유아와 친숙해지는 시 간을 가졌다. 검사 시에는 집에 영유아용 책상과 의자가 있는 경우 에는 의자에 앉게 하였으며, 없는 경우에는 집에 있는 낮은 테이블 에 앉아 진행하였다. 어머니는 영유아 옆쪽에 자리하도록 지시하였 으나, 혼자 착석이 어려운 일부 영유아의 경우는 어머니의 무릎에 앉힌 자세로 실시하였다. 검사 전에 양육자에게 검사의 목적과 절 차에 대해 설명하였으며, 검사 중에는 영유아에게 단서나 수행을 돕는 말과 몸짓을 하지 않도록 안내하였다. 특히 양육자가 참여하 는 놀이와 책 읽기 활동 중에는 놀이나 행동을 지시하거나 질문을 제공하지 말고 영유아가 시도하는 행동에 대해 반응해 주는 형태 로 참여하도록 상호작용 지침을 제공하였다. 추후 채점과 신뢰도 평가를 위하여 모든 절차는 보호자의 동의를 얻어 캠코더(Samsung DCR-SX83)로 녹화하였다.

\section{채점}

한국판 CSBS DP는 검사 매뉴얼에 제시된 채점 절차에 따라 채 점하였으며, 총점, 세 구성영역 점수, 7 개의 세부요인 점수, 그리고 문항별 점수를 측정하였다. 원검사의 채점 방식을 그대로 따랐으 며, 말소리 요인에 해당하는 2개의 문항만 Lee 등(2018)의 채점방법 을 따랐다.

\section{신뢰도}

신뢰도는 제 2 연구자에 의해 측정된 결과와 신뢰도 평가자 간의 일치도로 측정하였다. 신뢰도 평가자로는 언어병리학 석사과정에 있는 대학원생이 참여하였다. 신뢰도 평가자는 신뢰도 평가 전에 채점 기준 및 절차에 대해 교육을 받았으며, 실제 행동표본을 통하 여 연습을 실시하였다. 독립적인 신뢰도 평가는 연습 과정을 통해 채점자 간 일치도가 $.90(90 \%)$ 이상이 된 이후에 실시하였다. 신뢰 도 평가는 전체 자료의 약 $20 \%$ 에 해당하는 11 명의 자료를 무작위 로 추출하여 실시하였다. 연구자와 신뢰도 평가자가 각각 독립적으 로 각 영유아의 행동표본이 녹화된 자료를 보고 채점하였으며, 채 점된 결과에 대해 일치도를 측정하였다. 일치도는 측정한 결과를 관찰 기회(예: 정서 및 시선에서는 총 14 회의 관찰 기회가 제공됨)에 서 일치한 수를 일치와 불일치를 합한 수로 나누어 구하였으며, 그 결과 전체 일치도는 .99 , 세 구성영역 일치도는 $.98-.99,7$ 개의 세부요 인도.98-.99의 매우 높은 일치도를 보였다.

\section{통계분석}

통계분석은 SPSS 통계 프로그램(version 25)을 이용하여 실시하 
였다. 영유아 집단에 따른 한국판 CSBS DP 행동관찰검사의 총점 과 세 구성영역(사회적, 언어적, 상징적 영역)의 7 가지 세부요인(정 서 \& 시선, 의사소통, 몸짓, 말소리, 낱말, 언어이해, 사물사용놀이),

Table 2. Group differences in total score

\begin{tabular}{ccccccccc}
\hline & & & & & & \multicolumn{3}{c}{ Tukey } \\
\cline { 4 - 7 } & & & & & & \\
\cline { 6 - 8 } & & & & & LT-CA & LT-LA & CA-LA \\
\hline Total score & 90.67 & 124.11 & 76.28 & $17.72^{* * * *}$ & $* * *$ & & $* * * *$ \\
& $(21.38)$ & $(23.63)$ & $(28.64)$ & & & & \\
\hline
\end{tabular}

Values are presented as mean (SD).

$\mathrm{LT}=$ late talker; $\mathrm{CA}=$ chronological age matched group; $\mathrm{LA}=$ language age matched group.

${ }^{* * *} p<.001$.

Table 3. Group differences in 3 composites, 7 clusters, and 20 item scores

\begin{tabular}{|c|c|c|c|c|c|c|c|}
\hline & \multirow{2}{*}{ LT group } & \multirow{2}{*}{ CA group } & \multirow{2}{*}{ LA group } & \multirow{2}{*}{$F$} & \multicolumn{3}{|c|}{ Post-hoc } \\
\hline & & & & & LT-CA & LT-LA & CA-LA \\
\hline Social & $43.89(9.00)$ & $49.67(8.51)$ & $41.17(10.10)$ & $3.98^{*}$ & & & * \\
\hline Emotion \& gaze & $15.89(1.88)$ & $16.39(2.17)$ & $13.67(3.18)$ & $6.18^{* *}$ & & * & $* *$ \\
\hline Gaze shifts & $5.78(0.55)$ & $6.00(0.00)$ & $5.67(0.69)$ & 2.02 & & & \\
\hline Shared positive affect & $4.78(1.17)$ & $4.56(2.18)$ & $4.33(1.61)$ & .31 & & & \\
\hline Gaze/pointing following & $5.33(1.28)$ & $5.83(0.71)$ & $3.67(2.63)$ & $7.65^{* *}$ & & * & $* *$ \\
\hline Communication & $15.00(4.01)$ & $18.67(4.09)$ & $14.50(4.50)$ & $5.26^{* *}$ & * & & * \\
\hline Rate of communication & $5.11(1.08)$ & $5.33(0.97)$ & $5.06(1.26)$ & .32 & & & \\
\hline Behavior regulation & $4.83(0.99)$ & $5.17(0.99)$ & $4.83(1.15)$ & .61 & & & \\
\hline Social interaction & $2.39(1.85)$ & $4.28(1.87)$ & $2.44(1.76)$ & $6.23^{* *}$ & * & & * \\
\hline Joint attention & $2.72(1.78)$ & $3.89(1.88)$ & $2.17(1.86)$ & $4.13^{*}$ & & & * \\
\hline Gesture & $13.00(4.42)$ & $14.61(3.84)$ & $13.00(4.01)$ & .93 & & & \\
\hline Inventory of conventional gestures & $9.56(3.11)$ & $10.89(2.40)$ & $9.22(2.76)$ & 1.82 & & & \\
\hline Distal gestures & $3.44(1.69)$ & $3.72(1.93)$ & $3.78(1.99)$ & .16 & & & \\
\hline Speech & $13.56(7.96)$ & $36.78(12.30)$ & $15.22(12.39)$ & $24.61^{* * *}$ & $* *$ & & $* * *$ \\
\hline Sounds & $9.11(5.43)$ & $20.22(5.11)$ & $10.33(7.17)$ & $18.74^{* * *}$ & $* * *$ & & $* * *$ \\
\hline Syllables with consonants & $2.89(1.71)$ & $5.44(1.04)$ & $3.00(2.14)$ & $13.10^{* * *}$ & $* * *$ & & $* * *$ \\
\hline Inventory consonants & $6.22(4.11)$ & $14.78(4.29)$ & $7.33(5.44)$ & $17.99 * * *$ & $* * *$ & & $* * *$ \\
\hline Words & $4.44(2.87)$ & $16.56(7.90)$ & $4.89(5.86)$ & $24.26 * * *$ & $* * *$ & & $* * *$ \\
\hline Words & $2.50(1.69)$ & $5.00(1.50)$ & $2.28(2.14)$ & $12.78^{* * *}$ & $* * *$ & & $* * *$ \\
\hline Inventory of words & $1.67(1.33)$ & $5.89(2.49)$ & $1.83(2.07)$ & $25.20^{* * *}$ & $* * *$ & & $* * *$ \\
\hline Word combinations & $0.11(0.47)$ & $2.56(2.31)$ & $0.33(1.03)$ & $14.95^{* * *}$ & $* * *$ & & $* * *$ \\
\hline Inventory of word combination & $0.06(0.24)$ & $3.11(3.23)$ & $0.44(1.29)$ & $12.26^{* * *}$ & $* * *$ & & $* *$ \\
\hline Symbolic & $33.22(10.83)$ & $37.67(7.46)$ & $19.89(12.04)$ & $14.54^{* * *}$ & & $* *$ & $* * *$ \\
\hline Language comprehension & $18.44(6.20)$ & $21.50(3.29)$ & $10.50(8.62)$ & $14.07^{* * *}$ & & ** & $* * *$ \\
\hline Object use & $14.78(5.87)$ & $16.17(5.59)$ & $9.39(4.96)$ & $7.67^{* *}$ & & * & $* *$ \\
\hline Inventory of action schemes & $6.33(2.72)$ & $6.50(2.48)$ & $4.56(2.50)$ & 3.16 & & & \\
\hline Action schemes toward other & $3.28(1.71)$ & $3.67(1.71)$ & $2.83(1.82)$ & 1.02 & & & \\
\hline Sequences action schemes & $1.56(1.20)$ & $1.94(1.59)$ & $0.61(0.78)$ & $5.56^{* *}$ & & & $* *$ \\
\hline Stacks toward of blocks & $3.61(1.54)$ & $4.06(1.21)$ & $1.39(1.54)$ & $17.76^{* * *}$ & & $* * *$ & $* * *$ \\
\hline
\end{tabular}

Values are presented as mean (SD).

$\mathrm{LT}=$ late talker; $\mathrm{CA}=$ chronological age matched group; $\mathrm{LA}=$ language age matched group.

${ }^{*} p<.05,{ }^{* *} p<.01,{ }^{* * *} p<.001$.
20 개의 항목에 대해 일원분산분석(one-way ANOVA)으로 분석한 후 Tukey 사후분석을 실시하였다.

\section{연구결과}

\section{한국판 CSBS DP 총점 비교}

세 집단 간의 CSBS DP의 총점을 비교한 결과 세 집단 간 유의한 차이가 있었으며 $(F=17.72, p<.001)$, 말늦은 영유아 집단과 언어연 령일치 집단이 생활연령일치 집단에 비해 유의하게 낮은 점수를 나 타냈으며, 말늦은 영유아 집단과 언어연령일치 집단 간에는 유의한 차이가 없었다(Table 2). 


\section{한국판 CSBS DP 구성영역과 세부요인별 점수 비교}

한국판 CSBS DP의 세 구성영역인 사회적 영역 $(F=3.98, p<.05)$, 발화적 영역 $(F=24.61, p<.001)$, 상징적 영역 $(F=14.54, p<.001)$ 모 두에서 집단 간 유의한 차이가 있었다. 사회적 영역은 생활연령일 치 집단과 일반연령일치 집단 간에 유의한 차이가 있었으며 말늦은 영유아 집단과 생활연령일치 집단 그리고 언어연령일치 집단 간에 는 유의한 차이가 없었다. 발화적 영역에서는 말늦은 영유아 집단 과 언어연령일치 집단이 생활연령일치 집단에 비해 유의하게 낮은 점수를 보였으며, 말늦은 영유아 집단과 언어연령일치 집단 간에는 유의한 차이가 없었다. 상징적 영역에서는 언어연령일치 집단이 말 늦은 영유아 집단과 생활연령일치 집단에 비해 유의하게 낮은 점 수를 보였으며, 말늦은 영유아 집단과 생활연령일치 집단 간에는 유의한 차이가 없었다(Table 3).

한국판 CSBS DP 7가지 세부요인별로 차이 검정을 실시한 결과, 사회적 영역에서는 정서 및 시선( $F=6.18, p<.01)$, 의사소통 $(F=5.26$, $p<.01)$ 요인에서 집단 간 유의한 차이가 나타났으며, 몸짓 요인에 서는 유의한 차이가 없었다. 정서 및 시선 요인은 언어연령일치 집 단이 말늦은 영유아 집단과 생활연령일치 집단에 비해 유의하게 낮은 점수를 보였으며, 말늦은 영유아 집단과 생활연령일치 집단 간에는 유의한 차이가 없었다. 반면, 의사소통 요인은 말늦은 영유 아 집단과 언어연령일치 집단이 생활연령일치 집단에 비해 유의하 게 낮은 점수를 보였으며, 말늦은 영유아 집단과 언어연령일치 집단 간에는 유의한 차이가 없었다.

발화적 영역에서는 말소리 $(F=18.74, p<.001)$ 와 낱말 $(F=24.26$, $p<.001)$ 요인 모두 집단 간 차이를 보였으며, 말늦은 영유아 집단과 언어연령일치 집단이 생활연령일치 집단에 비해 유의하게 낮은 점 수를 보였으며, 말늦은 영유아 집단과 언어연령일치 집단 간에는 유의한차이가 없었다.

상징적 영역의 언어이해 $(F=14.07, p<.001)$ 와 사물사용 $(F=7.67$, $p<.01)$ 요인도 모두 두 집단 간 유의한 차이를 보였다. 언어연령일 치 집단이 말늦은 영유아 집단과 생활연령일치 집단에 비해 유의 하게 낮은 점수를 보였으며, 말늦은 영유아 집단과 생활연령일치 집단 간에는 유의한 차이가 없었다.

\section{한국판 CSBS DP 항목 점수 비교}

먼저 정서 및 눈 응시 요인은 시선이동, 긍정적 정서표현, 가리키 는 곳 바라보기 세 항목으로 구성되었는데, 이 중 가리키는 곳 바라 보기 항목 $(F=7.65, p<.01)$ 에서만 유의한 차이가 있었다. 언어연령 일치 집단이 말늦은 영유아 집단과 생활연령일치 집단에 비해 유 의하게 낮은 점수를 보였으며, 말늦은 영유아 집단과 생활연령일치
집단 간에는 유의한 차이가 없었다.

의사소통 요인은 의사소통행동 빈도, 행동통제, 사회적 상호작 용, 공동주의의 네 항목으로 구성되는데, 이 중 사회적 상호작용 $(F=6.23, p<.01)$, 공동주의 $(F=4.13, p<.05)$ 항목에서 유의한 차 이가 있었다. 사회적 상호작용 항목은 말늦은 영유아 집단은 생활 연령 집단에 비해 유의하게 낮은 점수를 보인 것으로 나타났으며, 공동주의 항목은 언어연령일치 집단이 생활연령일치 집단에 비해 유의하게 낮은 점수를 보인 것으로 나타났다.

몸짓 요인은 관습적 몸짓과 원거리 몸짓 항목으로 구성되며, 두 항목모두 세 집단 간 유의한 차이를 보이지 않았다.

말소리 요인은 이를 구성하는 두 항목인 자음 포함 음절 $(F=13.10$, $p<.001)$ 과 자음 목록 $(F=17.99, p<.001)$ 두 항목에서 모두 유의한 차이가 있었다. 두 항목 모두 말늦은 영유아 집단과 언어연령일치 집단이 생활연령일치 집단에 비해 유의하게 낮은 점수를 보였으며, 말늦은 영유아 집단과 언어연령 일치집단 간에는 유의한 차이가 없 는 것으로 나타났다.

낱말 요인 역시 이를 구성하는 낱말 $(F=12.78, p<.001)$ 과 낱말 목록 $(F=25.20, p<.001)$, 낱말조합 $(F=14.95, p<.001)$ 과 낱말조합 의 목록 $(F=12.26, p<.001)$ 모두 집단 간 유의한 차이를 보였다. 네 항목 모두 말늦은 영유아 집단과 언어연령일치 집단이 생활연령일 치 집단에 비해 유의하게 낮은 점수를 보였으며, 말늦은 영유아집단 과 언어연령일치 집단 간에는 유의한 차이가 없는 것으로 나타났다. 언어이해 요인은 하나의 항목으로 구성되며, 집단 간에 유의한 차 이가 있었으며 $F=14.07, p<.001)$, 언어연령일치 집단이 말늦은 영유 아 집단과 생활연령일치 집단에 비해 유의하게 낮은 점수를 보였다.

마지막으로 사물사용 요인은 행동도식 목록, 다른 사람을 향한 행동도식, 연속행동도식, 그리고 블록쌓기 네 항목으로 구성되는데, 이 중 연속행동도식 $(F=5.56, p<.01)$, 블록쌓기 $(F=17.76, p<.001)$ 에서 집단 간 차이를 보였다. 연속행동도식은 생활연령일치 집단과 언어연령일치 집단 사이에서만 유의한 차이가 나타났으며 말늦은 영유아 집단은 두 통제 집단과 유의한 차이를 보이지 않았다. 블록 쌓기의 경우는 언어연령일치 집단이 말늦은 영유아 집단과 생활연 령일치 집단에 비해 유의하게 낮은 점수를 보였으며, 말늦은 영유 아 집단과 생활연령일치 집단 간에는 유의한 차이가 없었다. 이상 에서 서술된 결과는 Table 3에 요약되어 있다.

\section{논의 및 결론}

본 연구는 한국판 CSBS DP 행동관찰검사를 이용하여 말늦은 영유아의 초기 사회적 의사소통행동을 측정하고 이를 생활연령을 
일치시킨 일반 영유아만이 아니라 언어연령을 일치시킨 일반 영유 아 집단의 수행과 비교함으로써 이들의 사회적 의사소통행동 발달 양상을 확인하고자 하였다.

\section{한국판 CSBS DP 총점과 세 구성영역 수행 결과 비교}

먼저, 세 집단 간의 한국판 CSBS DP의 총점을 비교한 결과, 말늦 은 영유아 집단이 생활연령일치 집단에 비해 유의하게 낮은 점수 를 보였으나 언어연령일치 집단과는 유의한 차이를 보이지 않았다. 이는 말늦은 영유아의 초기 사회적 의사소통행동 발달이 생활연 령보다는 자기보다 어린 영유아와 유사함을 보여준다. CSBS DP 총 점이 언어발달과 관련된다는 것은 선행연구를 통해 보고된 바 있 다. 한국판 CSBS DP의 신뢰도와 타당도 연구(Lee et al., 2018)에서 CSBS DP 총점이 SELSI의 수용언어연령, 표현언어연령, 통합언어연 령과 .759-.809의 높은 정적 상관관계가 있었다고 보고하였으며, Watt, Wetherby와 Shumway (2006)는 종단적 연구를 통해 2세 이 전에 CSBS DP로 측정한 사회적 의사소통 기술이 3 세의 언어능력 을 예측한다고 보고하기도 하였다. 본 연구의 결과는 말늦은 영유 아의 초기 사회적 의사소통 발달도 언어발달과 밀접하게 관련되어 있음을 보여 준다.

한국판 CSBS DP의 세 구성영역인 사회적, 발화적, 상징적 영역 수행 결과는 영역에 따라 다른 결과를 나타냈다. 사회적 영역은, 말 늦은 영유아 집단이 두 통제집단과 모두 유의한 차이가 없었다. 기 술통계 결과에서는 생활연령일치 집단이 가장 높은 점수를 보이 고, 그 다음 말늦은 영유아, 언어연령일치 집단의 순서를 보였으나 유의한 차이는 없었다. 반면, 발화적 영역에서는 말늦은 영유아 집 단이 생활연령일치 집단에 비해 유의하게 낮은 수행을 보였고, 상 징적 영역에서는 언어연령일치 집단에 비해서는 유의하게 높은 수 행을 보였다. 이는 말늦은 영유아가 말소리와 낱말, 낱말조합 산출 을 평가하는 발화적 영역은 언어수준이 같은 나이 어린 영유아와 유사한 수준으로 발달하는 반면, 언어이해와 상징놀이를 평가하 는 상징적 영역은 언어수준이 같은 나이 어린 영유아보다는 유의 하게 좋으며, 생활연령이 같은 또래와는 비슷한 수준으로 발달한 다는 것으로 해석할 수 있다. 한국판 CSBS DP 타당도 및 신뢰도 연구에서 Lee 등(2018)은 세 구성영역 중 사회적 영역과 상징적 영 역 점수는 18 개월 이전의 상대적으로 어린 시기의 발달을 더 민감 하게 반영하며, 발화적 영역은 18 개월 이후의 상대적으로 연령이 더 높은 영아들의 발달을 잘 보여주었다고 보고한 바 있는데, 이러 한 발달적 양상을 말늦은 영유아의 세 구성영역 수행에서도 확인 되었다.

\section{한국판 CSBS DP 세부요인과 항목별 수행 비교}

초기 사회적 의사소통행동의 세부요인별 특성을 확인하기 위하 여 한국판 CSBS DP의 7가지 세부요인과 그에 해당하는 항목 수행 을 세 집단 비교를 통해 살펴보았다. 먼저, 앞서 구성영역 결과에서 서술한 바와 같이 사회적 영역 점수에서는 집단 간에 유의한 차이 가 없었으나, 사회적 영역의 정서 및 시선, 의사소통 두 요인과 정서 및 시선 요인 중 가리키는 곳 바라보기 항목에서는 유의한 집단 간 의 차이가 있었다. 즉, 말늦은 영유아가 언어연령일치 집단에 비해 서는 유의하게 높은 수행을 보였으며, 생활연령일치 집단과는 유의 한 차이를 보이지 않았다. 이는 말늦은 영유아 집단이 의사소통 상 황에서 정서표현이나 시선 사용, 특히 가리키는 곳을 따라서 보는 행동이 언어연령이 일치된 어린 영유아들보다 생활연령을 일치한 영유아들과 비슷하게 발달함을 보여준다.

반면, 의사소통 요인과 이에 해당하는 항목 중 사회적 상호작용 은 생활연령일치 집단에 비해 유의하게 낮은 수행을 보였으며 언어 연령을 일치한 집단과는 유의한 차이를 보이지 않았다. 이는 의도 적 의사소통행동 전반과 사회적 상호작용 기능의 의사소통 행동이 같은 생활연령의 또래보다는 언어연령이 같은 더 나이 어린 영유아 와 유사함을 나타내는 것이다. 즉, 전반적 의도적 의사소통행동과 사회적 상호작용 기능의 의사소통행동 역시 언어발달 지연과 더불 어 제한된 발달을 보이는 것으로 이해할 수 있다. 공동주의 기능 항 목에서는 언어연령일치 집단이 생활연령일치 집단에 비해 유의하 게 낮은 수행을 보인 것으로 나타났으며, 말늦은 영유아는 두 통제 집단과 유의한 차이를 보이지 않았다. 공동주의 기능은 다른 기능 에 비해 언어발달과 밀접한 관계를 갖는다고 보고되나(Cho \& Lee, 2010; Lee, Lee, Lee, \& Lee, 2016; Lee \& Lee, 2018) 본 연구에서는 유 의한 차이는 없었다. 그러나 말늦은 영유아가 생활연령일치 집단보 다는 적은 빈도의 공동주의 기능을 보였고, 언어연령일치 집단보다 는 많은 빈도를 보여 공동주의 기능이 언어능력과 생활연령과 모 두 관련될 수 있음을 보여준다.

몸짓 요인과 여기에 포함된 관습적 몸짓과 원거리 몸짓 항목에 서는 모두 세 집단 간에 유의한 차이를 보이지 않았다. 이는 말늦은 영유아의 의사소통 몸짓이 제한되며(Lee \& Lee, 2015), 이후 언어발 달 회복을 확인해 주는 요인이 된다고 보고한(Hong \& Kim, 2005; Thal et al., 1991; Thal \& Tobias, 1992) 결과와는 다르다. 그러나 이 러한 차이는 선행연구는 의사소통 몸짓을 행동 샘플에서의 총 빈 도로 측정하거나 혹은 특정 실험과제를 사용한 것에 비해 CSBS $\mathrm{DP}$ 는 8 개의 몸짓 목록에서 해당되는 몸짓의 수와 6 회의 의사소통 유도 기회 중에서 원거리 몸짓을 사용한 빈도를 측정하기 때문에 상대적으로 영유아 몸짓 사용을 민감하게 측정하지 못한 것 때문 
에 나타난 것일 수 있다. 실제로 한국판 CSBS DP 신뢰도와 타당도 연구(Lee et al., 2018)에서도 몸짓 요인은 12-14개월과 다른 월령 집 단 간에서만 유의한 차이가 있었으며, 15 개월 이후의 월령 집단에 서는 유의한 차이가 없었다. 본 연구는 18-35개월 사이의 영유아를 대상으로 하였기 때문에 이 시기의 몸짓 사용을 CSBS DP가 민감 하게 측정하지 못하였을 가능성이 있다.

발화적 영역에서는 여기에 포함된 두 세부요인인 말소리와 낱말 요인, 그리고 이에 해당하는 6개 항목인 자음 포함 음절, 자음목록, 낱말 사용, 낱말목록, 낱말조합 사용, 낱말조합의 목록 모두 말늦은 영유아 집단과 언어연령일치 집단이 생활연령일치 집단에 비해 유 의하게 낮은 점수를 보였으며, 말늦은 영유아 집단과 언어연령일치 집단 간에는 유의한 차이가 없는 것으로 나타났다. 이는 말늦은 영 유아의 말소리 산출과 낱말사용, 낱말조합 능력이 모두 자기 생활 연령에 비해서 느리며, 자기보다 나이가 어린 언어연령이 일치된 영 유아 집단과 유사함을 보여주는 결과이다. 말늦은 영유아의 표현언 어능력이 표준화된 언어검사에서 10 백분위 미만에 해당하므로 당 연한 결과일 수도 있으나 언어표현만이 아니라 말소리 산출 또는 사용에서도 제한된다는 점은 강조될만 하다. 특히 말늦은 영유아 가 말소리 산출에서 느리다는 점은 여러 선행연구를 통해 반복적 으로 보고되었는데(Carson, Klee, Carson, \& Hime, 2003; Mirak \& Rescorla, 1998; Paul \& Jennings, 1992) CSBS DP와 같이 측정 기회 수가 제한된 검사 결과에서도 이러한 차이가 관찰된 것은 의미가 있 다고볼수 있다.

마지막으로 상징적 영역의 두 세부요인인 언어이해와 사물사용 요인, 그리고 사물사용 요인의 블록쌓기 항목은 모두 말늦은 영유 아 집단이 언어연령일치 집단에 비해서는 유의하게 높은 수행을 보 인 반면 생활연령일치 집단과는 유의한 차이를 보이지 않았다. 연 속행동도식은 생활연령일치 집단과 언어연령일치 집단 사이에서만 나타났으며, 말늦은 영유아 집단은 두 통제 집단과 유의한 차이를 보이지 않았다. 이와 같은 말늦은 영유아의 언어이해나 상징놀이 발달은 언어연령보다는 생활연령에 가깝다는 것을 나타낸다. 말늦 은 영유아는 언어표현 외에 다른 발달에서 유의한 발달문제를 보이 지 않기 때문에 언어이해나 상징놀이 발달에서 특별한 문제를 보이 지 않았을 수 있다. 선행연구에 따라서는 수용언어(Carson et al., 1998)나 상징놀이(Rescorla \& Goossens, 1992)에서도 제한되었다 고 보고하기도 하나 CSBS DP 수준에서 측정하는 간단한 이해나 상징놀이에서는 유의한 문제를 보이지 않는 것으로 확인되었다.

본 연구결과를 종합하면, 말늦은 영유아는 생활연령일치 집단 에 비해 한국판 CSBS DP 총점과 사회적 영역의 의사소통 요인, 발 화적 영역의 말소리와 낱말 요인에서 유의하게 낮은 수행을 보였으
며, 사회적 영역의 정서 및 응시 요인과 몸짓 요인, 상징적 요인의 언 어이해와 사물사용 요인에서는 유의한 차이를 보이지 않았다. 이 중 상징적 영역과 상징적 영역의 언어이해 및 사물사용 요인에서는 오히려 언어연령일치 집단에 비해 유의하게 높은 수행을 보였다. 이 러한 결과는 말늦은 영유아가 표현언어는 물론 전반적인 사회적 의 사소통행동 발달에서도 유의하게 제한되며, 낱말 산출 및 사용, 낱 말조합 산출 및 사용과 같은 표현언어 능력과 더불어 의도적 의사 소통행동, 말소리 산출 및 사용 측면에서도 취약함을 보여준다. 반 면 사회정서적 측면이나 언어이해, 사물사용과 관련된 상징적 측면 에서는 상대적 강점이 있음을 나타낸다.

본 연구는 한국판 CSBS DP 행동샘플검사를 통해 말늦은 영유 아의 초기 사회적 의사소통행동 발달 프로파일과 강약점을 확인 하였다는 점에서 의의가 있다. CSBS DP가 행동샘플에서 관찰되는 행동의 빈도를 모두 측정하는 것이 아니기 때문에 초기 사회적 의 사소통행동을 세세하게 측정하는 데에는 어느 정도 제한점이 있긴 하지만 그래도 행동관찰을 기반으로 비교적 용이하고 신뢰롭게 영 유아 행동을 확인할 수 있다는 장점이 있다. 본 연구의 결과는 말늦 은 영유아의 초기 사회적 의사소통행동을 이해하는 데 도움이 될 뿐 아니라, 나아가 한국판 CSBS DP를 활용하여 말늦은 영유아를 진단하고 평가할 때 유용한 자료가 되리라 기대한다. 이 연구를 기 반으로 추후 말늦은 영유아가 회복된 말늦은 영유아(RLT) 또는 늦되는 아동(late bloomer)으로 진전해 가는 요인을 확인해 보는 연 구도 의미가 있으리라 생각된다.

\section{REFERENCES}

Bavin, E. L., \& Bretherton, L. (2013). The early language in Victoria Study: late talkers, predictors, and outcomes. In L. Rescorla \& P. S. Dale (Eds.), Late talkers: language development, interventions, and outcomes (pp. 3-21). Baltimore, MD: Paul H. Brookes Publishing.

Bricker, D., Squires, J., Mounts, L., Potter, L., Nickel, R., Twombly, E., \& Farrell, J. (1999). Ages and stages questionnaire. Baltimore, MD: Paul H. Brookes.

Carson, C. P., Klee, T., Carson, D. K., \& Hime, L. K. (2003). Phonological profiles of 2-year-olds with delayed language development. American Journal of Speech-Language Pathology, 12(1), 28-39.

Carson, D. K., Klee, T., Perry, C. K., Muskina, G., \& Donaghy, T. (1998). Comparisons of children with delayed and normal language at 24 months of age on measures of behavioral difficulties, social and cognitive development. Infant Mental Health Journal, 19(1), 59-75. 
Cho, M. R., \& Lee, Y. K. (2010). Communicative behaviors of toddlers with or without language delay. Korean Journal of Early Childhood Special Education, 10(1), 31-46.

Choi, J. J., \& Lee, Y. (2018). Communicative gestures in prelinguistic periods as predictors of later language development in Korean toddlers. Communication Sciences \& Disorders, 23(1), 11-19.

Crais, E. R. (2011). Testing and beyond: strategies and tools for evaluating and assessing infants and toddlers. Language, Speech, and Hearing Services in Schools, 42(3), 341-364.

Dale, P. S., Price, T. S., Bishop, D. V., \& Plomin, R. (2003). Outcomes of early language delay. Journal of Speech, Language, and Hearing Research, 46(3), 544-560.

Desmarais, C., Sylvestre, A., Meyer, F., Bairati, I., \& Rouleau, N. (2008). Systematic review of the literature on characteristics of late-talking toddlers. International Journal of Language \& Communication Disorders, 43(4), 361389.

Ellis Weismer, S., \& Evans, J. L. (2002). The role of processing limitations in early identification of specific language impairment. Topics in Language Disorders, 22(3), 15-29.

Fenson, L. (2007). MacArthur-Bates communicative development inventories. Baltimore, MD: Paul H. Brookes Publishing.

Henrichs, J., Rescorla, L., Schenk, J. J., Schmidt, H. G., Jaddoe, V. W., Hofman, A., ... \& Tiemeier, H. (2011). Examining continuity of early expressive vocabulary development: the Generation R Study. Journal of Speech, Language, and Hearing Research, 54(3), 854-869.

Hong, G. H., \& Kim, Y. T. (2005). A longitudinal study of predictors for expressive vocabulary development of late-talkers. Communication Sciences \& Disorders, 10(1), 1-24.

Horwitz, S. M., Irwin, J. R., Briggs-Gowan, M. J., Heenan, J. M. B., Mendoza, J., \& Carter, A. S. (2003). Language delay in a community cohort of young children. Journal of the American Academy of Child \& Adolescent Psychiatry, 42(8), 932-940.

Jang, H. S., Seo, S. J., \& Ha, J. Y. (2008). Developmental assessment for the early intervention program planning. Seoul: Hakjisa.

Kim, Y. T., Kim, K. H., Yoon, H. R., \& Kim, H. S. (2003). Sequenced Language Scale for Infants (SELSI). Seoul: Special Education Publishing.

Klee, T., Carson, D. K., Gavin, W. J., Hall, L., Kent, A., \& Reece, S. (1998). Concurrent and predictive validity of an early language screening program. Journal of Speech, Language, and Hearing Research, 41(3), 627-641.

Lee, D. Y., \& Lee, Y. (2018). Effects of interactional context on intentional communicative acts of toddlers: focused on free play and book reading Communication Sciences \& Disorders, 23(3), 560-569.

Lee, Y., \& Lee, H. (2015). Communicative gestures in toddlers with developmental language delay and their relations to language development. Communication Sciences \& Disorders, 20(2), 255-265.

Lee, Y., Lee, H. (2016). Development of intentional communicative behavior in Korean toddlers 12 to 30 months. Communication Sciences \& Disorders, 21(4), 553-566.

Lee, Y., Lee, H., \& Choi, J. (2018). A study of validity and reliability of the CSBS DP behavior sample in Korean toddlers. Communication Sciences \& Disorders, 23(2), 539-548.

Mirak, J., \& Rescorla, L. (1998). Phonetic skills and vocabulary size in late talkers: concurrent and predictive relationships. Applied Psycholinguistics, 19(1), 1-17.

Paul, R. (1991). Profiles of toddlers with slow expressive language development. Topics in Language Disorders, 11(4), 1-13.

Paul, R. (1993). Outcomes of early expressive language delay. Journal of Childhood Communication Disorders, 15, 7-14.

Paul, R., \& Jennings, P. (1992). Phonological behavior in toddlers with slow expressive language development. Journal of Speech, Language, and Hearing Research, 35(1), 99-107.

Paul, R., Looney, S. S., \& Dahm, P. S. (1991). Communication and socialization skills at ages 2 and 3 in "late-talking" young children. Journal of Speech, Language, and Hearing Research, 34(4), 858-865.

Reilly, S., Bavin, E. L., Bretherton, L., Conway, L., Eadie, P., Cini, E., ... \& Wake, M. (2009). The Early Language in Victoria Study (ELVS): a prospective, longitudinal study of communication skills and expressive vocabulary development at 8, 12 and 24 months. International Journal of Speech-Language Pathology, 11(5), 344-357.

Rescorla, L. (1989). The Language Development Survey: a screening tool for delayed language in toddlers. Journal of Speech and Hearing Disorders, 54(4), 587-599.

Rescorla, L. (2002). Language and reading outcomes to age 9 in late-talking toddlers. Journal of Speech, Language, and Hearing Research, 45(2), 360371.

Rescorla, L. (2005). Age 13 language and reading outcomes in late-talking toddlers. Journal of Speech, Language, and Hearing Research, 48(2), 459472 .

Rescorla, L. (2009). Age 17 language and reading outcomes in late-talking toddlers: Support for a dimensional perspective on language delay. Journal 
of Speech, Language, and Hearing Research, 52(1), 16-30.

Rescorla, L. (2011). Late talkers: do good predictors of outcome exist? Developmental Disabilities Research Reviews, 17(2), 141-150.

Rescorla, L., \& Achenbach, T. M. (2002). Use of the Language Development Survey (LDS) in a national probability sample of children 18 to 35 months old. Journal of Speech, Language, and Hearing Research, 45(4), 733-743.

Rescorla, L., \& Goossens, M. (1992). Symbolic play development in toddlers with expressive specific language impairment (SLI-E). Journal of Speech, Language, and Hearing Research, 35(6), 1290-1302.

Rescorla, L., \& Merrin, L. (1998). Communicative intent in late-talking toddlers. Applied Psycholinguistics, 19(3), 393-414.

Rescorla, L., Roberts, J., \& Dahlsgaard, K. (1997). Late talkers at 2: outcome at age 3. Journal of Speech, Language, and Hearing Research, 40(3), 556-566.

Taylor, C., Zubrick, S., \& Rice, M. L. (2013). Population and public health perspectives on late language emergence at 24 months as a risk indicator for language impairment at 7 years. In Late talkers: In L. Rescorla \& P. S. Dale (Eds.), Late talkers: language development, interventions, and outcomes (pp. 23-40). Baltimore, MD: Paul H. Brookes Publishing.

Thal, D., Tobias, S., \& Morrison, D. (1991). Language and gesture in late talkers: a 1-year follow-up. Journal of Speech, Language, and Hearing Research, 34(3), 604-612.

Thal, D. J., Oroz, M., \& McCaw, V. (1995). Phonological and lexical develop- ment in normal and late-talking toddlers. Applied Psycholinguistics, 16(4), 407-424.

Thal, D. J., \& Tobias, S. (1992). Communicative gestures in children with delayed onset of oral expressive vocabulary. Journal of Speech, Language, and Hearing Research, 35(6), 1281-1289.

Tomblin, J. B., Records, N. L., Buckwalter, P., Zhang, X., Smith, E., \& O’Brien, M. (1997). Prevalence of specific language impairment in kindergarten children. Journal of Speech, Language, and Hearing Research, 40(6), 12451260.

Watt, N., Wetherby, A., \& Shumway, S. (2006). Prelinguistic predictors of language outcome at 3 years of age. Journal of Speech, Language, and Hearing Research, 49(6), 1224-1237.

Westerlund, M., Berglund, E., \& Eriksson, M. (2006). Can severely language delayed 3-year-olds be identified at 18 months? Evaluation of a screening version of the MacArthur-Bates Communicative Development Inventories. Journal of Speech, Language, and Hearing Research, 49(2), 237-247.

Wetherby, A. M., \& Prizant, B. M. (2002). CSBS DP manual: Communication and Symbolic Behavior Scales Developmental Profile. Baltimore, MD: Paul H. Brookes Publishing.

Whitehurst, G. J., \& Fischel, J. E. (1994). Practitioner review: Early developmental language delay: what. If anything. Should the clinician do about it? Journal of Child Psychology and Psychiatry, 35(4), 613-648. 


\section{국문초록}

\section{한국판 CSBS DP를 통한 말늦은 영유아의 초기 사회적 의사소통 프로파일 이윤경 · 이효주 \\ 한림대학교 언어청각학부}

배경 및 목적: 이 연구는 말늦은 영유아의 사회적 의사소통 프로파일을 각각 생활연령과 언어연령을 일치시킨 일반 영유아 집단과 비 교하여 살펴보는 것을 목적으로 하였다. 방법: 연구 대상은 $18-36$ 개월 사이의 말늦은 영유아 18 명과 생활연령을 일치시킨 일반 영유아 (생활연령일치 집단) 18 명, 언어연령을 일치시킨 일반 영유아(언어연령일치 집단) 18 명, 총 54 명의 영유아였다. 세 영유아 집단의 사회적 의사소통 행동은 한국판 의사소통 및 상징행동 척도 발달 프로파일(한국판 CSBS DP)의 행동샘플검사를 사용하여 평가하였으며, 검 사의 채점 체계에 따라 채점하였다. 측정된 점수는 일원분산분석과 Tukey 사후분석을 통해 통계 분석하였다. 결과: 말늦은 영유아 집 단은 한국판 CSBS DP 총점과 7개의 세부요인 중 의사소통, 말소리, 낱말 요인에서 생활연령일치 집단에 비해서만 유의하게 낮은 점수 를 나타냈다. 반면, 정서와 응시, 언어이해, 사물사용 요인에서는 생활연령일치 집단과 유의한 차이를 나타내지 않았으며, 언어연령일치 집단에 비해서는 유의하게 높은 점수를 보였다. 논의 및 결론: 본 연구 결과는 말늦은 영유아의 사회적 의사소통능력이 생활연령에 비 해 느리게 발달하며, 말소리나 낱말과 같은 발화적 측면과 의도적 의사소통행동과 요인에서 취약한 반면, 언어이해와 사물사용을 통한 상징놀이 측면에서는 상대적 강점을 가지는 것을 보여준다. 본 연구의 결과를 말늦은 영유아의 예후와 중재를 중심으로 논의하였다.

핵심어: 말늦은 영유아, 사회적 의사소통, 한국판 CSBS DP

본 논문은 2019년 한림대학교 학술연구비 지원으로 수행되었음(No. HRF-201904-010).

\section{참고문헌}

김영태, 김경희, 윤혜련, 김화수(2003). 영유아 언어발달검사(SELSI). 서울: 도서출판 특수교육.

이다예, 이윤경(2018). 상호작용 맥락이 영아의 의도적 의사소통행동에 미치는 영향: 책 읽기와 놀이를 중심으로. Communication Sciences \& Disorders, 23(3), 560-569

이윤경, 이효주(2015). 언어발달지체 영아의 의사소통적 제스처 특성과 언어발달과의 관계. Communication Sciences \& Disorders, 20(2), 255-265. 이윤경, 이효주(2016). 12-30개월 영유아의 의도적 의사소통 행동 발달. Communication Science \& Disorders, 21(4), 553-566.

이윤경, 이효주, 최지은(2018). 'CSBS DP 행동샘플검사' 한국판 표준화를 위한 타당도 및 신뢰도 연구. Communication Sciences \& Disorders, 23(2), 539-548.

장혜성, 서소정, 하지영(2008). 영아선별 교육진단검사. 서울: 학지사.

조미라, 이윤경(2010). 언어발달지체 유아와 일반 유아의 의사소통 행동 비교. 유아특수교육연구, 10(1),31-46.

최진주, 이윤경(2018). 언어이전 시기의 의사소통 몸짓 사용이 24 개월 언어발달에 미치는 영향에 관한 종단연구. Communication Sciences \& Disorders, 23(1), 11-19.

홍경훈, 김영태(2005). 종단연구를 통한 ‘말늦은아동 (late-talker)’의 표현어휘발달 예측요인 분석. 언어청각장애연구, 10(1), 1-24.

\section{ORCID}

이윤경(https://orcid.org/0000-0002-9759-6247); 이효주(https://orcid.org/0000-0002-6908-1836) 